\title{
Restricting daily time at pasture at low and high pasture allowance: Effects on pasture intake and behavioral adaptation of lactating dairy cows
}

\author{
E. Pérez-Ramírez, ${ }^{1}$ J. L. Peyraud, and R. Delagarde ${ }^{2}$ \\ INRA, UMR1080, Production du Lait, F-35590 Saint-Gilles, and Agrocampus Ouest, UMR1080, Production du Lait, F-35000 Rennes, France
}

\begin{abstract}
In pasture-based dairy systems, daily time at pasture is restricted during several periods of the year. The aim of this experiment was to evaluate the effect of restricting time at pasture on milk yield, pasture dry matter (DM) intake, and grazing behavior of dairy cows according to pasture allowance (PA), which partly defines pasture availability. The experiment was carried out in spring on strip-grazed perennial ryegrass pastures. The 6 treatments consisted of 3 durations of daily time at pasture [U: unrestricted day and night grazing $(22 \mathrm{~h}$ at pasture); R9: 1 grazing session restricted to $9 \mathrm{~h}$ between the 2 milkings; R5: 2 grazing sessions of $2.75 \mathrm{~h}$ after each milking) compared at low and high PA (13 and $24 \mathrm{~kg}$ of DM/d per cow $>5 \mathrm{~cm}$, respectively). Eighteen mid-lactation Holstein dairy cows were used according to a $6 \times 4$ incomplete Latin square design replicated 3 times with four 14-d periods. Pasture DM intake was measured by the ytterbium-fecal index method and grazing behavior from portable devices. On average, restricting time at pasture from $\mathrm{U}$ to $\mathrm{R}$ (mean of $\mathrm{R} 5$ + R9) decreased pasture intake by $2.9 \mathrm{~kg}$ of DM, milk yield by $1.3 \mathrm{~kg}$, and milk protein concentration by $0.11 \%$, and increased milk fat concentration by $0.20 \%$. Pasture intake and milk yield did not differ significantly between R9 and R5. The reduction of pasture intake and milk yield with decreasing time at pasture was greater at high compared with low PA. Grazing times were 536, 414, and $305 \mathrm{~min}$, representing proportions of time spent grazing of $0.40,0.77$, and 0.93 for treatments U, R9, and R5, respectively. The reduction of grazing time with decreasing time at pasture was greater at high compared with low PA. Pasture intake rate greatly increased with decreasing time at pasture, but mainly on R5 $(29.8,31.6$, and $42.1 \mathrm{~g}$ of $\mathrm{DM} / \mathrm{min}$
\end{abstract}

Received December 5, 2008.

Accepted March 21, 2009.

${ }^{1}$ Current address: Colegio de Postgraduados, Campus Puebla, 72760, Puebla, México.

${ }^{2}$ Corresponding author: remy.delagarde@rennes.inra.fr for $\mathrm{U}, \mathrm{R} 9$, and R5, respectively). The effect of time at pasture on pasture intake rate was unaffected by PA. In conclusion, the effect of restriction of time at pasture on pasture intake and milk yield becomes more marked as PA increases. Cows offered only 2 grazing sessions of $2.75 \mathrm{~h}$ after each milking maximized pasture intake rate and consumed pasture as much as in one 9-h grazing session.

Key words: time at pasture, grazing behavior, pasture intake, dairy cow

\section{INTRODUCTION}

In dairy production systems, feeding costs represent a high proportion of total production costs and feeding dairy cows at pasture generally reduces production costs (Dillon et al., 2005). Extending the grazing season is therefore a means of reducing feed costs (Chénais et al., 2001). This, however, implies grazing cows during periods of heavy rainfall, low temperature, and short day length with generally low pasture availability at the farm level requiring forage supplementation. During these periods, the daily time spent at pasture is often restricted, both to limit sward damage during wet conditions and to supplement cows indoors at night. Allowing dairy cows to graze a few hours per day can also improve their welfare compared with cows kept indoors (Dillon et al., 2005; Sairanen et al., 2006), reduce direct fecal and urine deposition to pasture compared with a full-grazing system (Kristensen et al., 2007), or increase grazing efficiency through manipulation of foraging behavior (Chilibroste et al., 2007).

Daily access time at pasture could thus be used as a grazing management tool but its influence on cow performance is not well known. In recent studies, it has been reported that, even with high supplementation levels, milk yield is generally reduced when daily time at pasture is less than $8 \mathrm{~h}$ (Mattiauda et al., 2003; Kristensen et al., 2007; Delaby et al., 2008). In 2 recent studies, it has been reported that dairy cows can react to a time constraint at grazing through an increase in the proportion of time spent grazing and in pasture intake rate (Pérez-Ramírez et al., 2008; Kennedy et al., 2009). Grazing conditions such as pasture allowance or 
sward height that partly determine pasture availability and pasture intake rate can potentially affect the adaptability of the cows to a time constraint (Iason et al., 1999; Ginane and Petit, 2005; Chilibroste et al., 2007).

The objective of this study was to test the hypothesis that unsupplemented dairy cows adapt better to a severe restriction of daily access time at pasture at high compared with low pasture allowance because of a greater ability of cows to increase their pasture intake rate at high pasture allowance when time at pasture is restricted.

\section{MATERIALS AND METHODS}

\section{Treatments, Experimental Design, and Animals}

The 6 treatments consisted of 3 durations of daily time at pasture $(22 \mathrm{~h}, 9 \mathrm{~h}$, or $5.5 \mathrm{~h})$, each compared at low and high pasture allowance (PA: 13 vs. $24 \mathrm{~kg}$ of $\mathrm{DM} / \mathrm{d}$ per cow $>5 \mathrm{~cm})$. For the unrestricted treatment $(\mathbf{U})$, the cows had access day and night to pasture, namely from 0830 to $1630 \mathrm{~h}$ and from 1730 to $0730 \mathrm{~h}$. For the restricted $9 \mathrm{~h}$ treatment (R9), the cows had access to the pasture only between the 2 milkings in one session of $9 \mathrm{~h}$, from 0815 to $1715 \mathrm{~h}$. For the restricted 5.5 h treatment (R5), the cows had access to the pasture during 2 sessions per day, from 0745 to $1030 \mathrm{~h}$ after the morning milking $(2.75 \mathrm{~h})$ and from 1700 to 1945 $\mathrm{h}$ after the evening milking $(2.75 \mathrm{~h})$. When they were not at pasture or at milking, the cows in treatments R5 and R9 were kept indoors in individual stalls, with free access to water and a salt block. They received neither forage nor concentrate as supplement. Procedures relating to care and use of cows in the current experiment were approved by an animal care committee of the French Ministry of Agriculture, in accordance with French regulations.

The experiment was conducted from April 21 to June 15,2006 , according to an incomplete $6 \times 4$ Latin square design replicated 3 times, with four 14-d successive periods. The first $8 \mathrm{~d}$ of each period were for adaptation to the treatment and the last $6 \mathrm{~d}$ for measurements. Eighteen lactating Holstein cows in the second half of lactation were split into 6 groups of 3 cows as similar as possible, each group being assigned a treatment sequence. Cows were grouped according to their lactation number $(2.8 \pm 1.4)$, DIM $(211 \pm 110 \mathrm{~d})$, milk yield at peak of the lactation curve $(41.2 \pm 7.1 \mathrm{~kg})$, along with milk yield $(28.7 \pm 6.6 \mathrm{~kg})$, milk fat concentration $(3.74$ $\pm 0.60 \%)$, milk protein concentration $(3.28 \pm 0.34 \%)$, and BW $(626 \pm 65 \mathrm{~kg})$, measured 1 wk before the start of the experiment.

\section{Pastures and Grazing Management}

This experiment was undertaken at the Institut National de la Recherche Agronomique (INRA) experimental farm of Méjusseaume $\left(1.71^{\circ} \mathrm{W}, 48.11^{\circ} \mathrm{N}\right.$; Brittany, France), on 2 paddocks of pure perennial ryegrass (Lolium perenne L. cv. 'Ohio') sown 4 yr previously. One paddock was used for periods 1 and 3 , and the second for periods 2 and 4 . Paddocks 1 and 2 were cut on April 3 and April 17, respectively, to homogenize sward height and to allow, on average, 3 wk of sward regrowth during experimental measurements. During the experiment, paddocks were longitudinally divided into 6 subpaddocks, one per treatment. The relative size of the subpaddocks was proportional to the corresponding PA. At the end of periods 1 and 2, refusals and ungrazed areas were mowed to a cutting height of $5 \mathrm{~cm}$ to obtain homogeneous regrowth between treatments during the last 2 periods. Paddocks received 60 $\mathrm{kg}$ of $\mathrm{N} / \mathrm{ha}$ as ammonium nitrate immediately after both cuts.

A strip-grazing system with front and back electric fence was applied throughout the experiment. The area allocated daily to each treatment was adjusted from a daily estimate of the pregrazing pasture mass by multiplying the pregrazing sward height and the sward bulk density (see below). Cows were moved to a new strip once daily after the morning milking. The back fence was moved $1 \mathrm{~d}$ after the front fence. Water was always available for each treatment, at pasture and indoors. A salt block was available to cows only indoors and during milking.

\section{Pasture Measurements}

Pregrazing pasture mass above $5 \mathrm{~cm}$ was measured on d $0,4,7$, and 11 of each period by cutting 2 strips of $0.5 \times 5 \mathrm{~m}$ per treatment with a motor scythe. Precut and postcut sward heights were measured on each cut strip with an electronic platemeter $(30 \times 30 \mathrm{~cm}, 4.5 \mathrm{~kg} /$ $\mathrm{m}^{2}$, Agro-Systèmes, La Membrolle, France) to calculate the depth of cutting. Sward bulk density was calculated on each strip by dividing herbage mass by the depth of cutting. Pasture DM concentration was determined on each cut strip from a 700-g subsample. The chemical composition of pasture offered was determined on dried subsamples from d 7 and 11, composited per treatment and period. Pasture mass below $5 \mathrm{~cm}$ was measured on $\mathrm{d} 7$ and 11 on each strip cut by motor scythe, by cutting the stubble with scissors at ground level in a representative $0.1-\mathrm{m}^{2}$ area. Stubble DM concentration was determined after manual removal of soil and roots if any. 
Pre- and postgrazing pasture height were determined daily from 30 random measurements per treatment with an electronic platemeter. Pregrazing extended tiller height was measured with a ruler on $\mathrm{d} 8$ and 12 from 40 randomly selected tillers per treatment. Postgrazing extended tiller height was measured on d 11, 12, and 14 from 100 randomly selected tillers per treatment.

The chemical composition of selected pasture was determined on d 8 and 12 from randomly selected pasture handfuls (minimum of $700 \mathrm{~g}$ fresh per treatment) cut with scissors at ground level before grazing. Handfuls were then frozen and cut at the postgrazing sward height as described by Pérez-Ramírez et al. (2008). The upper fraction was oven-dried before chemical analysis per period and treatment.

\section{Animal Measurements}

Milk yield was measured individually at each milking, carried out between 0700 and $0815 \mathrm{~h}$ and between 1615 and $1745 \mathrm{~h}$ according to the treatment. Milk fat and protein concentrations were determined at each milking from d 11 to 14 by near infrared spectrophotometry (Milkoscan, Foss Electric, Hillerød, Denmark). Body weight was measured on the last day of each period after the morning milking.

Individual pasture DMI was estimated from daily fecal output and OM digestibility of the selected pasture. Daily fecal output was estimated by dilution of ytterbium oxide and $\mathrm{OM}$ digestibility from fecal $\mathrm{CP}$ and ADF concentrations (fecal index method) as described previously by Ribeiro Filho et al. (2005). The ytterbium was incorporated in a pelleted cereal-based concentrate containing $0.5 \%$ ytterbium oxide $\left(\mathrm{Yb}_{2} \mathrm{O}_{3}\right)$. Throughout the experiment, each cow received, at each milking through the ruminal cannula, $200 \pm 0.5 \mathrm{~g}$ of this Yb-concentrate along with $40 \mathrm{~g}$ of colored plastic particles to identify dung during fecal sampling.

Pasture DMI was estimated in the last $5 \mathrm{~d}$ of each period from fecal sampling at pasture and indoors. At pasture, all dungs were sampled once daily in the morning. Indoors, frequent monitoring during the afternoon (R5), evening, and early in the morning ( $\mathrm{R} 5+\mathrm{R} 9)$ enabled us to identify and sample most of the dungs before cleaning. Fecal DM concentration was determined daily from a representative 200-g subsample of feces. These dried fecal samples were then composited by cow and period before chemical analysis.

Individual net energy balance was calculated in unité fourragère lait ( $\mathbf{U F L}=7.12 \mathrm{MJ}$ of $\mathrm{NE}_{\mathrm{L}}$ ) as the difference between net energy requirements for maintenance and milk yield and net energy supply from pasture and Yb-concentrate (INRA, 2007). Net energy supply from pasture was calculated from pasture DMI and from net energy concentration of the selected pasture.

Grazing bouts and daily grazing time were recorded automatically on each cow during 3 to $4 \mathrm{~d}$ at the end of each period by means of a portable device (Brun et al., 1984). The device distinguishes and records grazing and ruminating activities from the jaw movements detected by means of a small balloon placed on the lower jaw. Rumination time was not analyzed in this experiment as behavior was not recorded during periods when animals were indoors. The proportion of time spent grazing was calculated by dividing daily grazing time by total time spent on pasture. A grazing bout (meal) was defined as a grazing sequence of at least 7 min separated from another meal by a sequence of nongrazing activity of at least $7 \mathrm{~min}$ (Brun et al., 1984). Mean grazing bout duration was calculated by dividing daily grazing time by the number of grazing bouts. Mean pasture DM intake rate was calculated by dividing daily pasture DMI by daily grazing time.

\section{Chemical Analyses}

All oven-dried feed and fecal samples were ground through a $0.8-\mathrm{mm}$ screen before chemical analysis. The DM concentration was determined by drying in an oven at $80^{\circ} \mathrm{C}$ during $48 \mathrm{~h}$ for feeds and $72 \mathrm{~h}$ for feces. Ash was determined by calcination at $550^{\circ} \mathrm{C}$ for $5 \mathrm{~h}$ (Association Française de Normalisation, 1997) in a muffle furnace. Nitrogen concentration was determined by the Dumas method (Association Française de Normalisation, 1997) on a Leco apparatus (Leco, St. Joseph, MI). Pepsin-cellulase digestibility was determined according to Aufrère and Michalet-Doreau (1988). Concentrations of NDF, ADF, and acid detergent lignin were determined according to van Soest et al. (1991) on a Fibersac extraction unit (Ankom Technology, Fairport, NY). Ytterbium concentration was determined by atomic absorption spectrophotometry (Varian Spectraa-20, Varian France SA, Les Ulis, France), according to Siddons et al. (1985). Net energy value (in UFL; i.e., equivalent net energy to $1 \mathrm{~kg} \mathrm{DM}$ of barley, 7.12 MJ of net energy) and protein value (PDI, protein truly digested in the small intestine; INRA, 2007) of feeds were calculated from their chemical composition according to INRA (2007).

\section{Statistical Analyses}

Animal data averaged per cow and period were analyzed using PROC MIXED of SAS (version 8, SAS Institute Inc., Cary, NC) with the following model: 


$$
\begin{aligned}
\mathrm{Y}_{\mathrm{ijkl}}=\mu & + \text { cow }_{\mathrm{i}}+\text { period }_{\mathrm{j}}+\text { time }_{\mathrm{k}}+\text { allowance }_{\mathrm{l}} \\
& +\left[\text { time }_{\mathrm{k}} \times \text { allowance }_{\mathrm{l}}\right]+\varepsilon_{\mathrm{ijkl}},
\end{aligned}
$$

where $\mathrm{Y}_{\mathrm{ijkl}}, \mu, \operatorname{cow}_{\mathrm{i}}$, period $_{\mathrm{j}}$, time $\mathrm{k}$, allowance, , time $_{\mathrm{k}}$ $\times$ allowance $]$, and $\varepsilon_{\mathrm{ijkl}}$ represent the analyzed variable, the overall mean, the random effect of the cow, the fixed effect of the period, the fixed effect of time at pasture, the fixed effect of PA, the interaction time at pasture with PA, and the residual term, respectively. Two individual data were removed before animal statistical analyses because of cow illness.

Pasture and grazing data, averaged per treatment and period, were analyzed using PROC GLM (SAS Institute, 1990) according to the following model:

$$
\begin{aligned}
\mathrm{Y}_{\mathrm{jkl}} & =\mu+\text { period }_{\mathrm{j}}+\text { time }_{\mathrm{k}}+\text { allowance }_{\mathrm{l}} \\
& +\left[\text { time }_{\mathrm{k}} \times \text { allowance }_{\mathrm{l}}\right]+\varepsilon_{\mathrm{ijk} \mathrm{l}} .
\end{aligned}
$$

Five orthogonal contrasts were used to determine 1) the mean effect of a restriction of time at pasture from the control treatment ( $\mathrm{U}$ vs. R; i.e., U vs. R5 + R9); 2 ) the mean effect of a restriction of time at pasture from 9 to $5.5 \mathrm{~h}$ (R9 vs. R5); 3) the mean effect of PA; 4) the mean effect of the interaction between PA and the restriction of time at pasture $[\mathrm{PA} \times(\mathrm{U}$ vs. $\mathrm{R})]$; and $5)$ the mean effect of the interaction between PA and the restriction of time at pasture from 9 to $5.5 \mathrm{~h}[\mathrm{PA}$ $\times(\mathrm{R} 9$ vs. $\mathrm{R} 5)$ ].

\section{RESULTS}

\section{Pregrazing Pasture Characteristics}

Pregrazing pasture characteristics were not generally affected by treatments (Table 1). Pregrazing pasture mass, sward height, pasture $\mathrm{CP}$ concentration, OM digestibility, and nutritive value were unaffected by time at pasture. Pregrazing pasture DM, NDF, and ADF concentrations were slightly less on $\mathrm{R}$ than on U. Pregrazing pasture mass and sward height, measured by platemeter, tended to be greater at high compared with low PA $(P=0.07)$. Pasture ADF concentration was less at high compared with low PA $(P<0.001)$.

\section{Grazing Management and Postgrazing Pasture Characteristics}

Daily offered area and daily PA were unaffected by time at pasture (Table 2). Postgrazing sward height was greater on $\mathrm{R}$ than on $\mathrm{U}(+14 \mathrm{~mm} ; P<0.01)$, and did not differ between R9 and R5. It was greater at high compared with low PA $(+30 \mathrm{~mm} ; P<0.001)$. The OM digestibility and energy value of the selected pasture were greater on $\mathrm{R}$ than on $\mathrm{U}$ but only at low PA [interaction PA $\times(\mathrm{U}$ vs. $\mathrm{R}) ; P<0.01$ and $P<$ 0.01 , respectively]. The nutritive value of the selected pasture did not differ between R9 and R5 (Table 2). The OM digestibility, UFL, and PDI values of the selected pasture were greater at high compared with low PA $(P<0.001)$.

\section{Milk Yield, Milk Composition, and BW}

On average, milk yield was less on $\mathrm{R}$ than on $\mathrm{U}(-1.4$ $\mathrm{kg} / \mathrm{d} ; P<0.001$ ), with no difference between R9 and R5 (Table 3). This reduction tended to be greater at high compared with low PA $[-2.1$ vs. $-0.6 \mathrm{~kg} / \mathrm{d}$, interaction $\mathrm{PA} \times(\mathrm{U}$ vs. $\mathrm{R}) ; P=0.06]$. Milk protein yield had similar trends to milk yield. Milk fat yield was unaffected by time at pasture. Milk fat concentration increased $(+0.20 \% ; P<0.01)$ and milk protein concentration decreased $(-0.14 \% ; P<0.001)$ when time at pasture was restricted (Table 3). Milk protein concentration was on average less on $\mathrm{R} 5$ than on $\mathrm{R} 9(P<0.05)$, but this effect was significant only at low PA $[-0.11 \%$, interaction $\mathrm{PA} \times(\mathrm{R} 9$ vs. R5) $P<0.05]$. Body weight was less on $\mathrm{R}$ than on $\mathrm{U}(-30 \mathrm{~kg} ; P<0.001)$.

With increasing PA, milk yield $(+1.8 \mathrm{~kg} / \mathrm{d} ; P<$ $0.001)$, fat yield $(+53 \mathrm{~g} / \mathrm{d} ; P<0.01)$, protein yield $(+81$ $\mathrm{g} / \mathrm{d} ; P<0.001)$, milk protein concentration $(+0.12 \%$; $P<0.001)$, and BW $(+7 \mathrm{~kg} ; P<0.05)$ increased and milk fat concentration tended to decrease $(-0.11 \%$; $P$ $=0.07)$.

\section{Intake and Energy Balance}

Pasture DMI was on average less on $\mathrm{R}$ than on $\mathrm{U}$ $(-2.9 \mathrm{~kg} ; P<0.001)$, and this reduction was greater at high compared with low PA [-3.5 vs. $-2.2 \mathrm{~kg} \mathrm{DM} / \mathrm{d}$; interaction $\mathrm{PA} \times(\mathrm{U}$ vs. $\mathrm{R}) ; P<0.05]$. There was no significant difference in pasture DMI between R9 and R5 (Table 3). Energy balance was less on $\mathrm{R}$ than on $\mathrm{U}(-2.1 \mathrm{UFL} / \mathrm{d} ; P<0.001)$ and was similar between $\mathrm{R} 9$ and R5 at low PA, but was less on R5 than on R9 at high $\mathrm{PA}$ [interaction $\mathrm{PA} \times(\mathrm{R} 9$ vs. R5); $P<0.05$ ]. Pasture DMI $(+1.6 \mathrm{~kg} / \mathrm{d} ; P<0.001)$ and energy balance $(+1.4 \mathrm{UFL} / \mathrm{d} ; P<0.001)$ increased with increasing PA.

\section{Grazing Behavior}

Grazing time greatly decreased with decreasing time at pasture $(P<0.001)$, with on average 536,414 , and $305 \mathrm{~min}$ for $\mathrm{U}, \mathrm{R} 9$, and $\mathrm{R} 5$, respectively (Table 3 ). The grazing times on R9 and R5 were only 0.67 and 0.57 of the grazing time on $\mathrm{U}$. The difference in grazing time between $\mathrm{U}$ and the 2 restricted times at pasture was 
Table 1. Effects of time at pasture and pasture allowance on pregrazing pasture characteristics: pasture mass, sward height, chemical composition, and nutritive value of pasture offered

\begin{tabular}{|c|c|c|c|c|c|c|c|c|c|c|c|c|}
\hline \multirow[b]{3}{*}{ Item } & \multicolumn{6}{|c|}{ Treatment $^{1}$} & \multicolumn{6}{|c|}{ Contrast $^{1}$ ( $P$-value $)$} \\
\hline & \multicolumn{3}{|c|}{ Low PA } & \multicolumn{3}{|c|}{ High PA } & \multirow[b]{2}{*}{ SEM } & \multicolumn{2}{|c|}{$\mathrm{T}$} & \multirow[b]{2}{*}{ PA } & \multicolumn{2}{|c|}{ Interaction $\mathrm{T} \times \mathrm{PA}$} \\
\hline & $\mathrm{U}$ & R9 & $\mathrm{R} 5$ & $\mathrm{U}$ & $\mathrm{R} 9$ & R5 & & U vs. R & R9 vs. R5 & & $\begin{array}{c}\mathrm{PA} \times \\
(\mathrm{U} \text { vs. } \mathrm{R})\end{array}$ & $\begin{array}{c}\mathrm{PA} \times \\
(\mathrm{R} 9 \text { vs. R5) }\end{array}$ \\
\hline $\begin{array}{l}\text { Pasture mass, } \mathrm{kg} \text { DM/ha }>5 \mathrm{~cm} \\
\text { Pregrazing sward height, } \mathrm{mm}\end{array}$ & 3,000 & 3,100 & 3,150 & 3,310 & 3,280 & 3,150 & 98 & 0.881 & 0.689 & 0.061 & 0.208 & 0.355 \\
\hline Rising platemeter & 172 & 176 & 177 & 183 & 182 & 177 & 3.5 & 0.991 & 0.584 & 0.070 & 0.212 & 0.327 \\
\hline Extended tiller & 375 & 379 & 392 & 398 & 397 & 386 & 8.7 & 0.777 & 0.932 & 0.106 & 0.276 & 0.188 \\
\hline Extended sheath & 143 & 142 & 145 & 161 & 157 & 150 & 6.0 & 0.566 & 0.737 & 0.022 & 0.474 & 0.434 \\
\hline $\mathrm{DM}, \mathrm{g} / \mathrm{kg}$ & 151 & 143 & 145 & 148 & 146 & 143 & 2.8 & 0.036 & 0.746 & 0.860 & 0.456 & 0.344 \\
\hline \multicolumn{13}{|l|}{ Chemical composition, $\mathrm{g} / \mathrm{kg}$ of $\mathrm{DM}$} \\
\hline $\mathrm{OM}$ & 876 & 885 & 886 & 889 & 876 & 885 & 4.8 & 0.911 & 0.310 & 0.772 & 0.037 & 0.457 \\
\hline $\mathrm{CP}$ & 187 & 186 & 187 & 179 & 188 & 192 & 4.6 & 0.189 & 0.581 & 0.955 & 0.163 & 0.699 \\
\hline NDF & 548 & 533 & 527 & 540 & 532 & 524 & 6.4 & 0.018 & 0.318 & 0.448 & 0.564 & 0.881 \\
\hline $\mathrm{ADF}$ & 254 & 238 & 236 & 236 & 229 & 224 & 3.7 & 0.001 & 0.330 & 0.001 & 0.261 & 0.668 \\
\hline Acid detergent lignin & 20 & 18 & 18 & 18 & 18 & 21 & 1.3 & 0.765 & 0.311 & 0.702 & 0.111 & 0.453 \\
\hline \multicolumn{13}{|l|}{ Nutritive value $^{2}$} \\
\hline $\mathrm{OM}_{\text {digestibility }}^{3}$ & 0.763 & 0.777 & 0.778 & 0.773 & 0.770 & 0.774 & 0.0054 & 0.170 & 0.626 & 0.862 & 0.113 & 0.796 \\
\hline UFL, UFL/kg of DM & 1.01 & 1.04 & 1.04 & 1.03 & 1.02 & 1.03 & 0.009 & 0.122 & 0.554 & 0.931 & 0.109 & 0.749 \\
\hline PDIN, g/kg of DM & 121 & 121 & 122 & 116 & 122 & 125 & 3.0 & 0.189 & 0.578 & 0.956 & 0.163 & 0.695 \\
\hline PDIE, g/kg of DM & 106 & 107 & 108 & 106 & 107 & 108 & 1.0 & 0.119 & 0.530 & 0.895 & 0.942 & 0.691 \\
\hline
\end{tabular}

PDIE, g/kg of

${ }^{1}$ Treatments and contrasts: PA

time at pasture; $\mathrm{R}=\mathrm{R} 9+\mathrm{R} 5$.

$\underline{2}{ }^{2} \mathrm{UFL}=$ unité fourragère lait $=7.12 \mathrm{MJ}$ of $\mathrm{NE}_{\mathrm{t}}$; PDIN = protein truly digested in the intestine (nitrogen limiting microbial synthesis in the rumen); PDIE $=$ protein truly digested

$\underline{\mathrm{O}}$ in the intestine (energy limiting microbial synthesis in the rumen) (INRA, 2007).

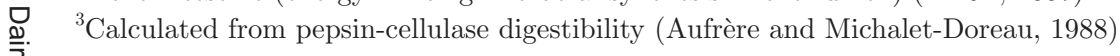




\begin{tabular}{|c|c|c|c|c|c|c|c|c|c|c|c|c|}
\hline \multirow[b]{3}{*}{ Item } & \multicolumn{6}{|c|}{ Treatment $^{1}$} & \multirow[b]{3}{*}{ SEM } & \multicolumn{5}{|c|}{ Contrast $^{1}$ ( $P$-value) } \\
\hline & \multicolumn{3}{|c|}{ Low PA } & \multicolumn{3}{|c|}{ High PA } & & \multicolumn{2}{|c|}{$\mathrm{T}$} & \multicolumn{3}{|c|}{ Interaction $\mathrm{T} \times \mathrm{PA}$} \\
\hline & $\mathrm{U}$ & $\mathrm{R} 9$ & $\mathrm{R} 5$ & $\mathrm{U}$ & $\mathrm{R} 9$ & $\mathrm{R} 5$ & & U vs. $\mathrm{R}$ & R9 vs. R5 & PA & $\begin{array}{c}\mathrm{PA} \times \\
(\mathrm{U} \text { vs. } \mathrm{R})\end{array}$ & $\begin{array}{c}\mathrm{PA} \times \\
(\mathrm{R} 9 \text { vs. R5) }\end{array}$ \\
\hline Offered area, $\mathrm{m}^{2} / \mathrm{d}$ & 50 & 47 & 44 & 75 & 76 & 80 & 2.8 & 0.782 & 0.740 & 0.001 & 0.122 & 0.239 \\
\hline Pasture allowance, $\mathrm{kg}$ of $\mathrm{DM} / \mathrm{d}$ & 13.1 & 13.2 & 13.2 & 23.7 & 23.8 & 23.9 & 0.49 & 0.779 & 0.942 & 0.001 & 0.909 & 0.898 \\
\hline \multicolumn{13}{|l|}{ Post-grazing sward height, mm } \\
\hline Rising platemeter & 65 & 74 & 82 & 93 & 106 & 111 & 3.3 & 0.001 & 0.086 & 0.001 & 0.781 & 0.729 \\
\hline Extended tiller & 86 & 98 & 104 & 129 & 150 & 163 & 8.0 & 0.008 & 0.254 & 0.001 & 0.369 & 0.647 \\
\hline Extended sheath & 79 & 89 & 95 & 113 & 125 & 131 & 6.2 & 0.019 & 0.381 & 0.001 & 0.812 & 0.978 \\
\hline \multicolumn{13}{|l|}{ Nutritive value of pasture selected ${ }^{2}$} \\
\hline $\mathrm{OM}$ digestibility ${ }^{3}$ & 0.797 & 0.823 & 0.823 & 0.825 & 0.835 & 0.828 & 0.0030 & 0.001 & 0.232 & 0.001 & 0.002 & 0.209 \\
\hline UFL, UFL/kg of DM & 1.07 & 1.11 & 1.11 & 1.12 & 1.14 & 1.12 & 0.005 & 0.001 & 0.263 & 0.001 & 0.003 & 0.208 \\
\hline PDIN, g/kg of DM & 125 & 129 & 134 & 139 & 148 & 143 & 2.8 & 0.026 & 0.980 & 0.001 & 0.907 & 0.093 \\
\hline PDIE, $\mathrm{g} / \mathrm{kg}$ of DM & 110 & 113 & 114 & 116 & 118 & 117 & 0.7 & 0.001 & 0.638 & 0.001 & 0.171 & 0.063 \\
\hline
\end{tabular}

${ }^{1}$ Treatments and contrasts: $\mathrm{PA}=$ pasture allowance; $\mathrm{U}=$ unrestricted time at pasture; $\mathrm{R} 9=$ time at pasture restricted to $9 \mathrm{~h} ; \mathrm{R} 5=$ time at pasture restricted to $2 \times 2.75 \mathrm{~h} ; \mathrm{T}=$ time at pasture; $\mathrm{R}=\mathrm{R} 9+\mathrm{R} 5$.

${ }^{2} \mathrm{UFL}=$ unité fourragère lait $=7.12 \mathrm{MJ}$ of $\mathrm{NE}_{\mathrm{L}}$; PDIN $=$ protein truly digested in the intestine (nitrogen limiting microbial synthesis in the rumen); PDIE $=$ protein truly digested in the intestine (energy limiting microbial synthesis in the rumen) (INRA, 2007).

${ }^{3}$ Estimated from fecal $\mathrm{N}$ and ADF concentrations.

Table 3. Effects of time at pasture and pasture allowance on milk yield, milk composition, BW, pasture intake, and feeding behavior in grazing dairy cows

\begin{tabular}{|c|c|c|c|c|c|c|c|c|c|c|c|c|}
\hline \multirow[b]{3}{*}{ Item } & \multicolumn{6}{|c|}{ Treatment $^{1}$} & \multicolumn{6}{|c|}{ Contrast $^{1}$ ( $P$-value $)$} \\
\hline & \multicolumn{3}{|c|}{ Low PA } & \multicolumn{3}{|c|}{ High PA } & \multirow[b]{2}{*}{ SEM } & \multicolumn{2}{|c|}{$\mathrm{T}$} & \multirow[b]{2}{*}{$\mathrm{PA}$} & \multicolumn{2}{|c|}{ Interaction $\mathrm{T} \times \mathrm{PA}$} \\
\hline & $\mathrm{U}$ & R9 & R5 & $\mathrm{U}$ & R9 & R5 & & U vs. R & R9 vs. R5 & & $\begin{array}{c}\mathrm{PA} \times \\
(\mathrm{U} \text { vs. } \mathrm{R})\end{array}$ & $\begin{array}{c}\mathrm{PA} \times \\
(\mathrm{R} 9 \text { vs. R5) }\end{array}$ \\
\hline Milk yield, $\mathrm{kg} / \mathrm{d}$ & 19.8 & 19.2 & 19.2 & 22.6 & 20.4 & 20.6 & 0.43 & 0.001 & 0.752 & 0.001 & 0.060 & 0.805 \\
\hline Fat yield, $\mathrm{g} / \mathrm{d}$ & 803 & 823 & 795 & 883 & 842 & 855 & 19.2 & 0.411 & 0.720 & 0.002 & 0.276 & 0.337 \\
\hline Protein yield, g/d & 597 & 575 & 558 & 726 & 622 & 625 & 13.1 & 0.001 & 0.612 & 0.001 & 0.006 & 0.500 \\
\hline Milk fat concentration, $\%$ & 4.12 & 4.34 & 4.17 & 3.94 & 4.19 & 4.18 & 0.068 & 0.004 & 0.225 & 0.064 & 0.361 & 0.289 \\
\hline Milk protein concentration, \% & 3.08 & 3.06 & 2.95 & 3.25 & 3.10 & 3.11 & 0.021 & 0.001 & 0.027 & 0.001 & 0.129 & 0.022 \\
\hline $\mathrm{BW}, \mathrm{kg}$ & 613 & 586 & 582 & 621 & 590 & 590 & 3.5 & 0.001 & 0.589 & 0.037 & 0.725 & 0.600 \\
\hline Pasture DMI ${ }^{2} \mathrm{~kg} / \mathrm{d}$ & 14.5 & 12.1 & 12.5 & 17.0 & 13.9 & 13.1 & 0.33 & 0.001 & 0.612 & 0.001 & 0.026 & 0.108 \\
\hline Energy balance, $\mathrm{UFL}^{3} / \mathrm{d}$ & 0.9 & -0.9 & -0.3 & 3.0 & 1.0 & -0.2 & 0.38 & 0.001 & 0.528 & 0.001 & 0.109 & 0.040 \\
\hline Grazing time, $\min / \mathrm{d}$ & 513 & 428 & 310 & 559 & 399 & 299 & 9.3 & 0.001 & 0.001 & 0.801 & 0.001 & 0.352 \\
\hline Proportion of time spent grazing & 0.38 & 0.80 & 0.94 & 0.42 & 0.74 & 0.91 & 0.012 & 0.001 & 0.001 & 0.067 & 0.001 & 0.217 \\
\hline First grazing bout duration, min & 168 & 211 & 163 & 133 & 176 & 153 & 9.8 & 0.007 & 0.002 & 0.003 & 0.476 & 0.255 \\
\hline Number of grazing bouts, $\mathrm{n}$ & 6.3 & 3.2 & 2.1 & 6.1 & 3.4 & 2.1 & 0.27 & 0.001 & 0.001 & 0.893 & 0.616 & 0.797 \\
\hline Mean grazing bout duration, min & 89 & 147 & 153 & 97 & 136 & 147 & 8.1 & 0.001 & 0.309 & 0.698 & 0.252 & 0.796 \\
\hline Pasture DM intake rate, $\mathrm{g} / \mathrm{min}$ & 28.5 & 28.0 & 40.6 & 31.1 & 35.3 & 43.6 & 1.17 & 0.001 & 0.001 & 0.001 & 0.244 & 0.091 \\
\hline
\end{tabular}

${ }^{1}$ Treatments and contrasts: $\mathrm{PA}=$ pasture allowance; $\mathrm{U}=$ unrestricted time at pasture; $\mathrm{R} 9=$ time at pasture restricted to $9 \mathrm{~h} ; \mathrm{R} 5=$ time at pasture restricted to $2 \times 2.75 \mathrm{~h} ; \mathrm{T}=$ time at pasture; $\mathrm{R}=\mathrm{R} 9+\mathrm{R} 5$.

${ }^{2}$ For total DMI, add $0.4 \mathrm{~kg}$ of $\mathrm{DM} / \mathrm{d}$ of $\mathrm{Yb}$ pellets.

${ }^{3} \mathrm{UFL}=$ unité fourragère lait $=7.12 \mathrm{MJ}$ of $\mathrm{NE}_{\mathrm{L}}$ (INRA, 2007). 
greater at high compared with low PA [interaction PA $\times(\mathrm{U}$ vs. $\mathrm{R}) ; P<0.001]$. Cows increased the proportion of time spent grazing when time at pasture decreased, with on average $0.40,0.77$, and 0.93 for $\mathrm{U}, \mathrm{R} 9$, and R5, respectively. This increase was less at high compared with low $\mathrm{PA}$ [interaction $\mathrm{PA} \times(\mathrm{U}$ vs. $\mathrm{R}) ; P<0.001$ ].

The first grazing bout duration was greater on R9 than on $\mathrm{U}$ (194 vs. $151 \mathrm{~min} ; P<0.01$ ) but less on R5 (158 min) because of the limited time at pasture imposed [2.75 h (165 min)]. The number of grazing bouts per day dropped sharply with decreasing time at pasture $(P<0.001)$, with $6.2,3.3$, and 2.1 grazing bouts/d for U, R9, and R5, respectively. The mean grazing bout duration was greater on $\mathrm{R}$ than on $\mathrm{U}$ (146 vs. $93 \mathrm{~min}$; $P$ $<0.001$ ) and did not vary between R9 and R5.

On U, cows had a main grazing bout after each milking with an average of 45 to $55 \mathrm{~min}$ grazing/h, a medium rate of grazing activity during the afternoon (30 to 35 min grazing/h), and very little grazing at night (Figure 1 ). On R9, the first grazing bout was very intense ( 55 to $60 \mathrm{~min}$ grazing/h), followed by a short period of medium grazing activity, and finally an intense grazing bout of approximately $3 \mathrm{~h}$ before returning to the barn for evening milking (50 min grazing/h). On R5, grazing activity was intense and continuous during the time available at pasture.

Pasture intake rate was greater on $\mathrm{R}$ than on $\mathrm{U}(P<$ 0.001) irrespective of PA, but this increase was really significant only on R5 (contrast R9 vs. R5; $P<0.001$ ). On average, pasture intake rate was $29.8,31.6$, and 42.1 $\mathrm{g}$ of $\mathrm{DM} / \mathrm{min}$ for $\mathrm{U}, \mathrm{R} 9$, and R5, respectively. Pasture intake rate on R9 and R5 represented 1.06 and 1.41 of pasture intake rate on $\mathrm{U}$, respectively. The increase in pasture intake rate between $\mathrm{R} 9$ and $\mathrm{R} 5$ tended to be greater at low compared with high PA [interaction PA $\times(\mathrm{R} 9$ vs. $\mathrm{R} 5) ; P=0.10]$.

Grazing time, number of grazing bouts, and mean grazing bout duration were unaffected by PA (Table $3)$. The duration of the first grazing bout was less $(-27$ $\min ; P<0.01)$ and the pasture intake rate was greater $(+4.3 \mathrm{~g}$ of $\mathrm{DM} / \mathrm{min} ; P<0.001)$ at high compared with low PA.

\section{DISCUSSION}

The 2 main objectives of this study were 1) to quantify the effect of a restriction of time at pasture on pasture DMI and milk production, and 2) to determine whether the behavioral adaptability of cows to a restricted time at pasture is affected by PA. Cows were deliberately unsupplemented to increase their motivation to graze and highlight their adaptability to a time constraint. Initially, the most restricted daily time at pasture was planned to be a single 4-h grazing session, but a short preliminary study indicated that this restriction was too severe and led to a severe reduction in milk yield. The most restricted time at pasture was then fixed at $5.5 \mathrm{~h}$ and split into 2 daily sessions. Under these conditions, the results indicated a reduction of pasture DMI and milk yield from 22 to $9 \mathrm{~h}$ of access, but no further reduction of DMI and milk yield between $9 \mathrm{~h}$ and $2 \times$ $2.75 \mathrm{~h}$ of access. Moreover, contrary to our hypothesis, cows were more sensitive to time at pasture at high than at low PA.

\section{Reduction of Time at Pasture from 22 to $9 \mathrm{~h}$}

The reduction of milk yield observed between 22 and $9 \mathrm{~h}$ of access was previously reported in dairy cows. Chilibroste et al. (2004) reported a reduction of 3.0 $\mathrm{kg} / \mathrm{d}$ of milk yield between 16 and $8 \mathrm{~h}$ of access in unsupplemented dairy cows producing on average 22 $\mathrm{kg}$ of milk. Delaby et al. (2008) reported a reduction of $1.6 \mathrm{~kg} / \mathrm{d}$ of milk yield between 21 and $8 \mathrm{~h}$ of access in dairy cows producing $29 \mathrm{~kg}$ of milk and supplemented with $5 \mathrm{~kg}$ of $\mathrm{DM} / \mathrm{d}$ of a TMR based on corn silage. In other studies, the effect of time at pasture on milk yield was not significant in the range 22 to $8 \mathrm{~h}$ of access (Mattiauda et al., 2004; Kennedy et al., 2009). These results could be explained by the low level of milk yield in the study of Mattiauda et al. (2004) and by the high nutritive value of grazed pasture along with a concentrate supplementation level of $3 \mathrm{~kg}$ (Kennedy et al., 2009). Similarly to the current experiment, Kennedy et al. (2009) observed a significant reduction of pasture DMI $(1.7 \mathrm{~kg} / \mathrm{d})$ when time at pasture was reduced from 22 to $9 \mathrm{~h}$ given in one single session per day. These authors, however, reported no reduction of pasture DMI when the 9-h access was split in two 4.5-h sessions after each milking.

Most other studies conducted on ruminants with low nutritional requirements indicate that daily time at pasture in the 8- to 24 -h range does not affect pasture DMI: Iason et al. (1999) in ewes grazing tall swards, Gekara et al. (2005) in beef cattle, and Berhan et al. (2005) in goats. Contrary to these results, the current study and those undertaken in dairy cows receiving no supplementation or low levels of supplementation indicated that lactating cows were unable to eat as much in $9 \mathrm{~h}$ as in $20 \mathrm{~h}$ at pasture.

Similar pasture DMI levels at 9 and $22 \mathrm{~h}$ of access would imply a strong behavioral adaptation, for instance by increasing the proportion of time spent grazing or by increasing pasture intake rate or both, to compensate for the imposed time constraint. In the current study, the behavioral adaptation in this range of time at pasture was only partially observed, with a great increase in the proportion of time spent grazing but a 
(A) Time at pasture: $22 \mathrm{~h}$

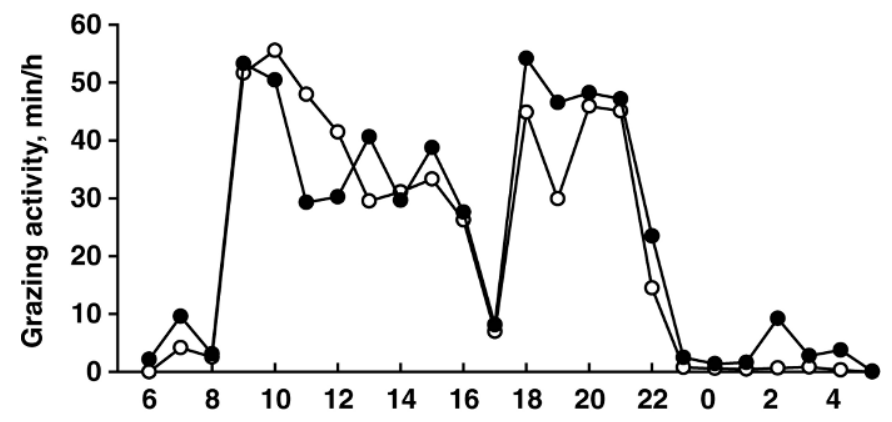

(B) Time at pasture: $9 \mathrm{~h}$

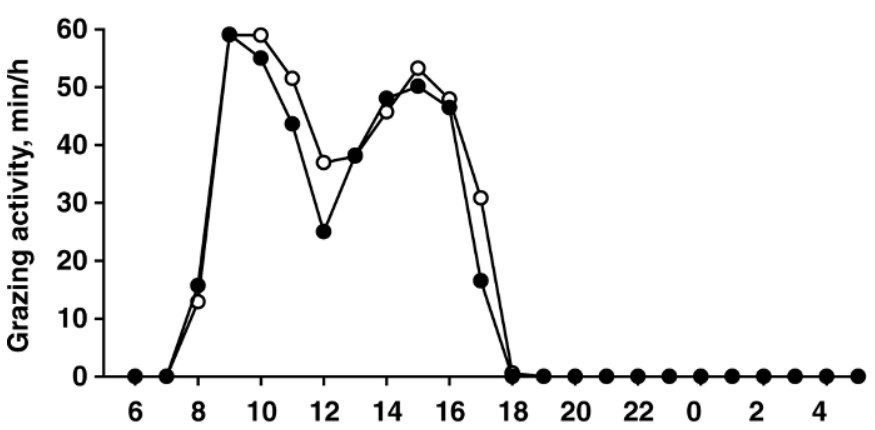

(C) Time at pasture: $2 \times 2.75 \mathrm{~h}$

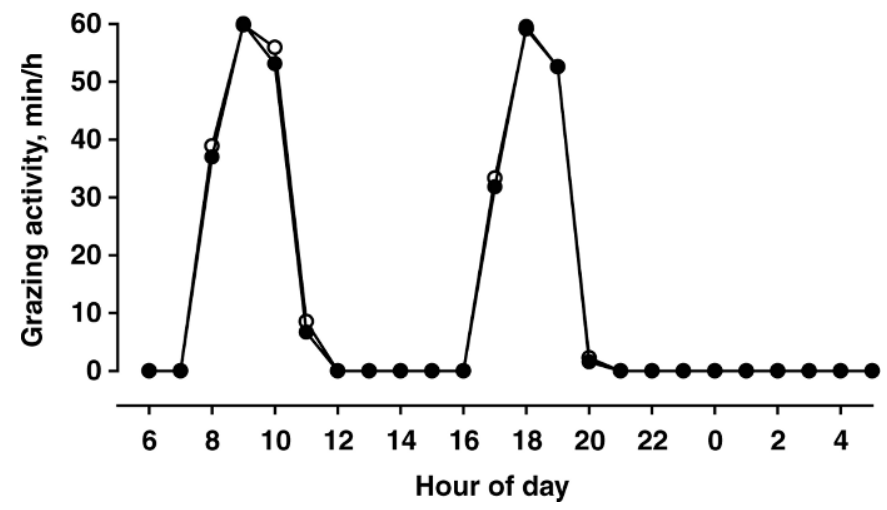

Figure 1. Daily pattern of grazing activity of dairy cows according to pasture allowance ( $=$ high; $\mathrm{O}=$ low $)$ and time at pasture. A) Unrestricted daily time at pasture, $22 \mathrm{~h} ; \mathrm{B}$ ) = daily time at pasture restricted to $9 \mathrm{~h}$ in one session between milkings; and C) = daily time at pasture restricted to $5.5 \mathrm{~h}$ in 2 sessions of $2.75 \mathrm{~h}$ after each milking.

small increase in pasture intake rate. The increase in the proportion of available time spent grazing allowed the cows to compensate half of the relative decrease of time at pasture $(-60 \%)$ because grazing time was finally reduced by only $33 \%$. This strong ability of dairy cows to concentrate their grazing activities in the time available to graze has been reported in previous studies in dairy cows (Mattiauda et al., 2004; Kennedy et al., 2009), beef cattle (Soca et al., 2002; Gekara et al., 2005), and small ruminants (Iason et al., 1999; Berhan et al., 2005). The low increase in pasture intake rate $(+6 \%)$ between 22 and $9 \mathrm{~h}$ of access is consistent with the recent results of Kennedy et al. (2009) on dairy cows. Those authors observed an $8 \%$ increase in pasture intake rate between 22 and $9 \mathrm{~h}$ of access offered in one single session between milkings as in the current experiment. In their study, the increase in pasture intake rate between 22 and $9 \mathrm{~h}$ of access was greater $(+16 \%)$ when the 9-h access was given in two 4.5-h sessions after each milking. This probably indicates that grazing dairy cows cannot maintain a high pasture intake rate during a long grazing session of $9 \mathrm{~h}$.

Other studies conducted in beef cattle or sheep indicated a greater increase in pasture intake rate in the same range of time at pasture. Gekara et al. (2005) reported in beef cattle a $14 \%$ increase in pasture intake rate between 24 and $12 \mathrm{~h}$ of access. Iason et al. (1999) reported with ewes a 35\% increase in pasture intake rate between 24 and $9.5 \mathrm{~h}$ of access, regardless of sward height. These increases in intake rate allowed cattle and sheep to maintain their DMI level at the shortest time at pasture.

In the current study, the reasons why cows were unable to increase their pasture intake rate at 9-h access are not obvious, especially considering that cows were not supplemented and that their high level of energy requirements could have increased their motivation to graze compared with other studies. Digestive and metabolic factors regulating intake may play an important role in this limitation as suggested by the daily pattern of grazing activities. Cows with 9-h access stopped their grazing activity at midday, indicating that physical and physiological satiety signals were greater than hunger signals in cows with either 9 or $22 \mathrm{~h}$ of access. Their second intense grazing period of $3 \mathrm{~h}$ before evening milking indicates that cows are able to anticipate the end of the access period, because the cows provided 22 $\mathrm{h}$ of access did not increase their grazing activity before evening milking. This second grazing bout is thus forced, occurring only 1 or $2 \mathrm{~h}$ after the first long grazing bout, thus probably preventing high intake rate.

\section{Reduction of Time at Pasture from 9 to $5.5 h(2 \times 2.75 h)$}

In the current study, the absence of a reduction in pasture DMI and milk yield between 9 and $5.5 \mathrm{~h}$ of access was not expected. The effect of time at pasture on dairy cow performance should be more marked as time at pasture decreases (Delagarde and O'Donovan, 2005). Short time at pasture (i.e., 4 to $5 \mathrm{~h} / \mathrm{d}$ ) given in one single session has already been studied but only with high supplementation levels ( 5 to $10 \mathrm{~kg}$ of DM/d; Kristensen et al., 2007; Delaby et al., 2008; Pérez-Ramírez 
et al., 2008). These studies indicate a significant effect of time at pasture in the range of 9 to $4 \mathrm{~h}$ on pasture DMI $(-1.7$ to $-2.3 \mathrm{~kg} / \mathrm{d})$ and milk yield $(-1.3$ to -2.1 $\mathrm{kg} / \mathrm{d}$ ) despite the high supplementation level that could theoretically limit intake response to time at pasture. Chilibroste et al. (2004) failed to observe a decrease in milk yield between 8 and $6 \mathrm{~h}$ of access, probably because of the small difference between the 2 times at pasture studied. In the study of Kennedy et al. (2009), two 3 -h grazing sessions per day, as in our study, allowed cows to maintain pasture DMI and milk yield compared with one 9-h session of access. In the current study, along with that of Kennedy et al. (2009), the absence of effect of time at pasture between 9 and 5.5 $\mathrm{h}$ on DMI and milk production seems to be ascribable to the splitting of the shortest time at pasture into 2 sessions per day.

The analysis of feeding behavior indicates that splitting the 5.5-h access into two 2.75 -h sessions per day really allowed cows to maximize their potential for adaptation compared with a single 9-h session. With two 2.75-h sessions, cows were continuously grazing throughout the available time. During both sessions, cows were generally removed from the paddock before the natural end of the meal. A proportion of time spent grazing close to or greater than $90 \%$ has already been reported by Berhan et al. (2005), Ginane and Petit (2005), Kristensen et al. (2007), and Kennedy et al. (2009) for short times at pasture of 4 to 6 h daily. The most noticeable behavioral adaptation is, however, the great increase in the average pasture intake rate at $5.5 \mathrm{~h}$ compared with 9 and $22 \mathrm{~h}$ of access, with $+33 \%$ and $+41 \%$, respectively. Kennedy et al. (2009) also reported a $35 \%$ increase in pasture intake rate between one 9-h grazing session and two 3 -h grazing sessions daily. In these 2 studies, the ability of cows to strongly increase their pasture intake rate was determinant for maintaining DMI and performance level. It can be suggested that the great increase in intake rate with two 2.75 -h grazing sessions results from a maximum stimulation of cow hunger during each session, following 2 long fasting periods each day (Chilibroste et al., 1997). With 2 short grazing sessions per day, meals are voluntarily well separated and shortened, and satiety mechanisms leading to a deceleration of intake rate at the end of a meal are probably minimized (Baumont, 1996). With times at pasture less than $5 \mathrm{~h}$ offered in one session daily, great increases in pasture intake rate $(+25$ to $50 \%)$ were also observed in dairy cows (Kristensen et al., 2007; Pérez-Ramírez et al., 2008), heifers (Ginane and Petit, 2005), and goats (Berhan et al., 2005).

\section{Interaction Between Time at Pasture and Pasture Allowance}

Cows' sensitivity to a restriction of time at pasture increased with PA, which is contrary to our initial hypothesis. The current study demonstrates that cows always need time for grazing, and particularly to be able to eat more pasture when PA increases. In other words, the well-described positive effect of PA on pasture DMI can be observed only if time at pasture is not limited.

Chilibroste et al. (2004) and Mattiauda et al. (2004) also studied the interaction between time at pasture (16 vs. $8 \mathrm{~h}$ ) and PA. Chilibroste et al. (2004) reported additive effects of time at pasture and PA on milk yield. Mattiauda et al. (2004) reported an interaction between time at pasture and PA contrary to that of our study, the negative effect of restricting time at pasture on milk yield being more marked at low than at high PA.

In the current study, the increase in pasture intake rate at $5.5 \mathrm{~h}$ of access was not affected by PA. This implies that increasing PA is not a good way to allow the cows to better adapt to a restriction of time at pasture. This can be related to the relatively small effect of PA on the average intake rate in strip-grazing systems. In fact, grazing conditions and sward height of the defoliated strata are actually modified by PA only during the second half of the grazing down process. In the current study, even with no limiting time at pasture, pasture intake rate increased only by $9 \%$ between low and high PA, which is a small variation compared with the variation of pasture intake rate observed between times at pasture (35\%).

\section{CONCLUSIONS}

Unsupplemented lactating dairy cows subjected to a restriction of daily time at pasture $(9 \mathrm{~h}$ in 1 session or $5.5 \mathrm{~h}$ in 2 sessions) were unable to maintain pasture DMI and milk yield compared with unrestricted cows, with no difference between 9 and $2 \times 2.75 \mathrm{~h}$. The average effect of time at pasture on pasture DMI, milk yield, and grazing time was greater at high than at low PA. Increasing PA allowed an increase in pasture DMI and milk yield mainly in the cows unrestricted by time at pasture, but did not allow the cows to better adapt to a restriction of time at pasture. The behavioral adaptation to a restriction of time at pasture was partial and dependent upon the duration of the restriction and on the daily number of grazing sessions. The cows always had excellent ability to focus their grazing activity during the time available for grazing, but a variable ability to increase their pasture intake rate. Only allocating 
the shortest time at pasture in 2 grazing sessions per day after each milking allowed cows to maximize pasture intake rate, leading to similar pasture DMI with 5.5 and $9 \mathrm{~h}$ of access.

\section{ACKNOWLEDGMENTS}

The Consejo Nacional de Ciencia y Tecnología (CONACYT, México) is gratefully acknowledged for financing the PhD studies of E. Pérez-Ramírez. This study was partly financed by the Agence Nationale de la Recherche (ANR, France) in the framework of the Praiterre programme (ANR-05-PADD-02-006). Many thanks are due to P. Lamberton, A. Cozien, D. Chevrel, M. Texier, J. L. Harel, B. Gréhal, T. Boudou, G. Théaud, and R. Ricou (INRA, UMR1080, Production du Lait, Domaine de Méjusseaume, France) for milking, feeding, and care of the cows, for measurements and data processing throughout the experiment, and also to A. Brasseur, N. Huchet, and T. Le Mouel (INRA, UMR1080, Production du Lait, Saint-Gilles, France) for laboratory chemical analyses.

\section{REFERENCES}

Association Française de Normalisation. 1997. Aliments des animauxDosage de l'azote-Méthode par combustion (DUMAS)-NF V18120; Dosage des cendres brutes-NF V18-101. AFNOR Editions, Saint-Denis La Plaine, France.

Aufrère, J., and B. Michalat-Doreau. 1988. Comparison of methods for predicting digestibility of feeds. Anim. Feed Sci. Technol. 20:203-218.

Baumont, R. 1996. Palatability and feeding behaviour in ruminants. Ann. Zootech. 45:385-400.

Berhan, T., R. Puchala, T. Sahlu, R. C. Merkel, and A. L. Goetsch. 2005. Effects of length of pasture access on energy use by growing meat goats. J. Appl. Anim. Res. 28:1-7.

Brun, J. P., S. Prache, and G. Béchet. 1984. A portable device for eating behaviour studies. In Proc. 5th Mtg. Eur. Graz. Workshop, Hill Farming Research Organisation, Midlothian, UK.

Chénais, F., J. M. Seuret, P. Brunschwig, and J. L. Fiorelli. 2001. Pour un rôle croissant du pâturage dans les systèmes bovins laitiers. Fourrages 166:257-277.

Chilibroste, P., D. A. Mattiauda, F. Elizondo, and A. Coster. 2004. Herbage allowance and grazing session allocation of dairy cowseffects on milk production and composition. In Proc. 2nd Symp. Grassl. Ecophysiol. Graz. Ecol., Curitiba, Brazil.

Chilibroste, P., P. Soca, D. A. Mattiauda, O. Bentancur, and H. Robinson. 2007. Short term fasting as a tool to design effective grazing strategies for lactating dairy cattle-A review. Aust. J. Exp. Agric. 47:1075-1084.

Chilibroste, P., S. Tamminga, and H. Boer. 1997. Effects of length of grazing session, rumen fill and starvation time before grazing on dry-matter intake, ingestive behaviour and dry-matter rumen pool sizes of grazing lactating dairy cows. Grass Forage Sci. 52:249-257.

Delaby, L., J. L. Peyraud, E. Pérez-Ramírez, and R. Delagarde. 2008. Effect and carryover effect of spring grazing access time on dairy cow performance. Grassl. Sci. Eur. 13:759-761.
Delagarde, R., and M. O'Donovan. 2005. Modelling of herbage intake and milk production by grazing dairy cows. Pages 89-104 in Proc. Satellite Workshop 20th Int. Grassl. Congr., Cork, Ireland. Utilisation Grazed Grass in Temp. Anim. Syst. J. J. Murphy, ed. Wageningen Academic Publishers, Wageningen, the Netherlands.

Dillon, P., J. R. Roche, L. Shalloo, and B. Horan. 2005. Optimising financial return from grazing in temperate pastures. Pages 131-147 in Proc. Satellite Workshop 20th Int. Grassl. Congr., Cork, Ireland. Utilisation Grazed Grass in Temp. Anim. Syst. J. J. Murphy, ed. Wageningen Academic Publishers, Wageningen, the Netherlands.

Gekara, O. J., E. C. Prigge, W. B. Bryan, E. L. Nestor, and G. Seidel. 2005. Influence of sward height, daily timing of concentrate supplementation, and restricted time for grazing on forage utilization by lactating beef cows. J. Anim. Sci. 83:1435-1444.

Ginane, C., and M. Petit. 2005. Constraining the time available to graze reinforces heifer' preference for sward of high quality despite low availability. Appl. Anim. Behav. Sci. 94:1-14.

Iason, G. R., A. R. Mantecon, D. A. Sim, J. Gonzalez, E. Foreman, F. F. Bermudez, and D. A. Elston. 1999. Can grazing sheep compensate for a daily foraging time constraint? J. Anim. Ecol. 68:87-93.

INRA. 2007. Alimentation des Bovins, Ovins et Caprins: Besoins des animaux, Valeurs des aliments. Editions QUAE, Versailles, France.

Kennedy, E., M. McEvoy, J. P. Murphy, and M. O'Donovan. 2009. Effect of restricted access time to pasture on dairy cow milk production, grazing behavior and dry matter intake. J. Dairy Sci. 92:168-176.

Kristensen, T., F. Oudshoorn, L. Munksgaard, and K. Søegaard. 2007. Effect of time at pasture combined with restricted indoor feeding on production and behaviour in dairy cows. Animal 1:439-448.

Mattiauda, D. A., S. Tamminga, F. Elizondo, and P. Chilibroste. 2003. Effect of the length and moment of the grazing session on milk production and composition of grazing dairy cows. Trop. Subtrop. Agroecosyst. 3:87-90.

Mattiauda, D. A., S. Tamminga, F. Elizondo, M. Gibb, and P. Chilibroste. 2004. Effect of allowance and timing grazing session on dairy cows grazing permanent pasture. In Proc. 2nd Symp. Grassl. Ecophysiol. Graz. Ecol., Curitiba, Brazil.

Pérez-Ramírez, E., R. Delagarde, and L. Delaby. 2008. Herbage intake and behavioural adaptation of grazing dairy cows by restricting time at pasture under two feeding regimes. Animal 2:1384-1392.

Ribeiro Filho, H. M. N., R. Delagarde, and J. L. Peyraud. 2005. Herbage intake and milk yield of dairy cows grazing perennial ryegrass swards or white clover/perennial ryegrass swards at low- and medium-herbage allowances. Anim. Feed Sci. Technol. 119:13-27.

Sairanen, A., H. Khalili, P. Virkajärvi, and J. Hakosalo. 2006. Comparison of part-time grazing and indoor silage feeding on milk production. Agric. Food Sci. 15:280-292.

SAS Institute. 1990. SAS User's Guide: Statistics. Version 6. SAS Inst. Inc., Cary, NC.

Siddons, R. C., D. E. Paradine, D. E. Beever, and P. R. Cornell. 1985. Ytterbium acetate as a particulate digesta flow marker. Br. J. Nutr. 54:509-519.

Soca, P., V. Beretta, M. Heizen, and O. Bentancur. 2002. Effect of pasture height and control of grazing time on grazing behaviour and defoliation dynamics of growing beef cattle. Pages 132-133 in Proc. Symp. Resp. Incr. Global Demand Anim. Prod., Yucatán, México.

Van Soest, P. J., J. B. Roberson, and B. A. Lewis. 1991. Carbohydrate methodology, metabolism, and nutritional implications in dairy cattle. J. Dairy Sci. 75:2215-2225. 